\title{
What You Export Matters: Does It Really?
}

\author{
Martin Grancay' ${ }^{1}$ Nora Grancay' ${ }^{1}$ Tomas Dudas ${ }^{1}$
}

\begin{abstract}
In 2007, Hausmann, Hwang and Rodrik (HHR) demonstrated that export specialization patterns have important implications for economic growth. The authors developed an indicator of income level linked to the country's exports they called EXPY and showed that higher values of the indicator lead to higher subsequent economic growth. The present paper tests whether HHR's conclusions are valid even in times of economic crisis and rising prices of primary commodities, using data from 2004-2013. We show that, in the aggregate, higher values of EXPY are connected with faster economic growth. However, the relationship is much more statistically significant in countries that focus heavily on exporting primary commodities than in other countries. This implies that the rising prices of primary commodities in the last decade have altered the traditional link between export sophistication and economic growth. As a result, we argue that EXPY is not a good predictor of future economic performance when the prices of primary commodities are unstable. Policy makers must be aware that, while what countries export is important, it is equally important when they export it: in times of stable prices of primary commodities, a focus on the export of sophisticated goods generates higher economic growth in the future. In times of rising prices of primary commodities, however, the effects can be exactly the opposite.
\end{abstract}

KEY WORDS: $\quad$ international trade, EXPY, export patterns, economic growth, terms of trade

JEL Classification: F14

${ }^{1}$ University of Economics in Bratislava - Faculty of International Relations, Slovakia

\section{Introduction}

The question of why some countries are rich and others are poor has been present in the economic literature for decades. Multiple theories have been developed stressing the importance of geographical factors (Diamond, 1997), diseases and institutions (Acemoglu, Johnson \& Robinson, 2001), and culture (Weber, 1950). While all of these works have focused mostly on historical primary determinants of economic growth, some other scholars have been searching for

Correspondence concerning this article should be addressed to: Martin Grancay, University of Economics in Bratislava - Faculty of International Relations, Dolnozemska cesta 1/B, Bratislava 85235, Slovakia. E-mail: martin_grancay@yahoo.com more contemporary secondary factors. The typical determinants identified include higher initial schooling and life expectancy, lower fertility, lower government consumption, better maintenance of the rule of law, lower inflation, improvements in the terms of trade (Barro, 1997), higher investment rates, and financial sector development (Prochniak, 2011), as well as some interregional factors such as income convergence and spatial spillovers (Crespo Cuaresma, Doppelhofer \& Feldkircher, 2014).

Hausmann, Hwang and Rodrik (2007) showed that the structure of exports is also one of the important determinants of economic growth. The authors developed an indicator called EXPY that captures the productivity level associated with a country's specializa- 
tion patterns on the basis of its export structure and can also be interpreted as a measure of the quality of the country's export basket. HHR proved that "countries that latch on to a set of goods that are placed higher on this quality spectrum tend to perform better" (p. 24). Their results are based on data for the period 1962-2003.

The aim of the present paper is to test the link between export quality and growth using the most recent data. We come from the assumption that dot.com crisis, the impact of the World Trade Center attacks and the great financial and economic crisis have significantly changed the global economic environment (Lipkova, 2012). As a result, it is doubtful whether "old conclusions" are still valid. We show that events of the last 15 years have altered the traditional link between export sophistication and economic growth and that EXPY is not a good predictor of future economic performance when the prices of primary commodities are unstable. Moreover, increasing quality of exports does not guarantee rising terms of trade.

In addition to theoretical contributions, our research has important policy implications. In demonstrating that higher export productivity does not necessarily accelerate growth and enhance the terms of trade, we show that countries can improve their economic performance even when focusing on primary commodities. In times of economic crisis, their exports appear to be more advantageous than the export of goods placed higher on the quality spectrum.

The remainder of the paper is organized as follows. Section 2 presents the idea behind the EXPY indicator and offers a brief literature review. Section 3 details and justifies the methods applied in this paper. Section 4 tests the hypothesis that higher productivity of exports leads to higher economic growth. In section 5, a link between productivity of exports and net barter terms of trade is explored. The final section concludes.

\section{Literature review - the EXPY concept}

In a widely cited paper, HHR (2007) introduced a measure of productivity level associated with a country's exports that they called EXPY. The basic idea behind the concept goes back two decades to Michaely (1984), and it captures the average level of income generated globally by the commodities the country exports. High values of EXPY indicate that the country's export patterns are dominated by high-income products, whereas low values mean that exports are dominated by lowincome goods.

To calculate EXPY, a PRODY index must be constructed first. PRODY is "a weighted average of the per capita GDPs of countries exporting a given product, and thus represents the income level associated with that product" (p. 9). For each product $k$ it equals

$\operatorname{PRODY}_{k}=\sum_{j} \frac{\left(x_{j k} / X_{j}\right)}{\sum_{j}\left(x_{j k} / X_{j}\right)} \cdot Y_{j}$

where the numerator is the value-share of the commodity in country j's overall export basket and the denominator aggregates the value-shares across all countries exporting the good. Following HHR, both $x$ and $X$ in the equation stand for exports, the difference being that $X$ represents the total exports of a country $j$, while $x$ is the country's exports of a product $k$. $Y$ stands for per capita GDP. A similar index was independently developed by Lall, Weiss and Zhang (2006), but never gained wide use.

In 2013, the product items with the highest associated income levels were plastic waste, parings and scrap, watches, clocks, fur skins and jewelry (table 1). On the other end of the list, crude fertilizers, nickel ores, tobacco and natural abrasives had the lowest PRODY values.

The EXPY of a country is defined as a weighted average of the PRODYs for that country, where the weights are the value shares of the products in the country's total exports:

$$
E X P Y_{i}=\sum_{l}\left(\frac{x_{i l}}{X_{i}}\right) \cdot P R O D Y_{l}
$$

Following the original notation, $i$ is the country index, $l$ is the product index, $x$ are the exports of a product $l$ by country $i$, and $X$ are the total exports of country $i$.

According to the theory, the higher the EXPY, the more productive a country's exports are. Generally, export productivity can be used as a proxy for export sophistication. An important exception to this rule is oilexporting countries, which tend to have high values of EXPY owing to the relatively high PRODY of oil and its large share of exporters' total exports. Switzerland, Ireland and Macao top the list, with Nauru, Somalia 
Table 1. Product items with the highest and lowest values of PRODY in 2013

\begin{tabular}{|c|c|c|c|}
\hline Product item & PRODY & Product item & PRODY \\
\hline [579] Waste, parings and scrap, of plastics & 61,111 & $\begin{array}{l}\text { [272] Crude fertilizers (excluding those of } \\
\text { division 56) }\end{array}$ & 1,367 \\
\hline [885] Watches \& clocks & 58,255 & $\begin{array}{l}\text { [284] Nickel ores \& concentrates; nickel } \\
\text { mattes, etc. }\end{array}$ & 2,692 \\
\hline $\begin{array}{l}\text { [613] Furskins, tanned or dressed, excluding } \\
\text { those of } 8483\end{array}$ & 56,832 & $\begin{array}{l}\text { [121] Tobacco, unmanufactured; tobacco } \\
\text { refuse }\end{array}$ & 2,829 \\
\hline $\begin{array}{l}\text { [897] Jewelry \& articles of precious material, } \\
\text { n.e.s. }\end{array}$ & 40,024 & $\begin{array}{l}\text { [277] Natural abrasives, n.e.s. (incl. industrial } \\
\text { diamonds) }\end{array}$ & 2,923 \\
\hline $\begin{array}{l}\text { [515] Organo-inorganic, heterocycl. } \\
\text { compounds, nucl. acids }\end{array}$ & 39,340 & $\begin{array}{l}\text { [001] Live animals other than animals of } \\
\text { division } 03\end{array}$ & 3,403 \\
\hline $\begin{array}{l}\text { [677] Rails \& railway track construction mat., } \\
\text { iron, steel }\end{array}$ & 35,338 & $\begin{array}{l}\text { [286] Ores and concentrates of uranium or } \\
\text { thorium }\end{array}$ & 3,680 \\
\hline [516] Other organic chemicals & 34,984 & [072] Cocoa & 3,752 \\
\hline [343] Natural gas, liquefied and not & 34,073 & [263] Cotton & 3,854 \\
\hline [514] Nitrogen-function compounds & 33,688 & [074] Tea and mate & 3,894 \\
\hline $\begin{array}{l}\text { [541] Medicinal and pharmaceutical } \\
\text { products, excluding } 542\end{array}$ & 32,995 & [075] Spices & 4,029 \\
\hline
\end{tabular}

Note: Values in PPP-adjusted current international dollars based on 206 countries and territories of the world at three digit level SITC Revision 3 commodity classification.

Source: Own calculations based on "UNCTADstat", by the UNCTAD (2014). Retrieved from http://unctadstat.unctad.org/wds/ ReportFolders/reportFolders.aspx; “GDP per capita, PPP (current international \$)”, by The World Bank (2014a). Retrieved from http://data.worldbank.org/indicator/NY.GDP.PCAP.PP.CD

and Malawi having the lowest values of the indicator. Qatar, Brunei, Turkmenistan and Algeria belong to the oil-related exceptions (table 2).

In their 2007 paper, HHR showed that there are "economically meaningful differences in the specialization patterns of otherwise similar countries" (p. 24) and came to the main conclusion that the income level of a country's exports predicts subsequent economic growth. Since then, hundreds of studies using the approach have been published. Among the most prominent ones, Santos-Paulino (2010; 2011) applied EXPY to China, India, Brazil and South Africa and found evidence of "productivity-enhancing effects of higher technology manufactured exports and of productivity-limiting effects of primaryresource based exports" (Santos-Paulino, 2010, p. 1107). Minondo (2010a) extended the approach by distinguishing between quality differences within a product category and applied it to Spanish provinces (Minondo, 2010b). He showed that there is a positive link between an exports' productivity and growth at a regional level. Saadi (2012) investigated the link between EXPY and net barter terms of trade. Interestingly, he found that the increase in the sophistication of the developing countries' exports is accompanied by a deterioration in their terms of trade. This par- 
Table 2. Countries with the highest and lowest values of EXPY in 2013

\begin{tabular}{|c|c|c|c|}
\hline Country or territory & EXPY & Country or territory & EXPY \\
\hline Switzerland & 28,705 & Nauru & 2,379 \\
\hline Ireland & 26,540 & Somalia & 4,124 \\
\hline China, Macao SAR & 25,668 & Malawi & 5,568 \\
\hline Qatar & 25,193 & Marshall Islands & 6,709 \\
\hline Brunei Darussalam & 25,112 & Zimbabwe & 6,864 \\
\hline Singapore & 23,761 & Solomon Islands & 6,913 \\
\hline China, Hong Kong SAR & 23,357 & British Virgin Islands & 6,942 \\
\hline China, Taiwan Province of & 23,182 & Comoros & 7,023 \\
\hline Turkmenistan & 22,938 & Guinea-Bissau & 7,357 \\
\hline Algeria & 22,818 & Burkina Faso & 7,599 \\
\hline
\end{tabular}

Note: Values in PPP-adjusted current international dollars based on 206 countries and territories of the world at three digit level SITC Revision 3 commodity classification.

Source: Own calculations based on "UNCTADstat", by the UNCTAD (2014). Retrieved from http://unctadstat.unctad.org/wds/ ReportFolders/reportFolders.aspx; "GDP per capita, PPP (current international \$)”, by The World Bank (2014a). Retrieved from http://data.worldbank.org/indicator/NY.GDP.PCAP.PP.CD

tially contradicts HHR's original results because, if higher export productivity is found to increase subsequent economic growth, it should also be the case that it enhances the terms of trade.

Other notable recent studies include Nyarko's (2013) application of the model to Sub-Saharan Africa, Bernatonyte's (2011) analysis of the export productivity of the Baltic nations, Weiss's (2010) discussion of how changes in trade structure affect growth and Jarreau and Poncet's (2011) study of the regional variation in export sophistication in China.

While the EXPY indicator has become widely used, it is not without critics; it rests on the uncertain assumption that more advanced countries produce sophisticated goods and conceals diversity in the quality and subtypes of goods (Wang, Wei \& Wong, 2010). Moreover, as illustrated by Johnson (2014, p. 138), "what countries export may be very different from what they actually contribute to the production process;" hence, the index fails to capture trade with processing goods. This criticism has to be kept in mind when drawing conclusions.

\section{Methodology}

Our research builds on HHR (2007) and Saadi (2012) and tests their conclusions in the period 2004-2013. We examine the links between export quality (proxied by EXPY) and economic growth and between export quality and net barter terms of trade using pooled ordinary least squares regression analysis with time-specific effects and heteroskedasticity-corrected OLS. The latter approach runs an auxiliary regression to generate an estimate of the error variance of the basic OLS, then estimating parameters using weighted least squares, where weights are the reciprocals of the estimated variance. PRODY and EXPY values for all products and countries and territories of the world have been calculated using UNCTAD (2014) export data at the three digit level SITC, Rev. 3 commodity classification. The input data set includes 206 countries and territories (see Appendix) and 255 product lines. Following the standard approach, trade values are nominal. Independent variables used in cross-national growth regressions are those identified by the original HHR (2007) paper. They include GDP per capita, EXPY, population 

Table 3. Cross-national growth regressions, 2004-2013

\begin{tabular}{|c|c|c|c|c|c|c|c|c|c|c|}
\hline & \multirow{2}{*}{\multicolumn{3}{|c|}{$\begin{array}{l}\text { Pooled OLS } \\
\text { All countries }\end{array}$}} & \multicolumn{7}{|c|}{ Heteroskedasticity-corrected OLS } \\
\hline & & & & \multicolumn{3}{|c|}{ All countries } & \multicolumn{2}{|c|}{ Primary } & \multicolumn{2}{|c|}{ Other } \\
\hline & (1) & (2) & (3) & (4) & (5) & (6) & (7) & (8) & (9) & (10) \\
\hline Log initial GDPcap & $\begin{array}{c}-0.06^{* * *} \\
(0.02)\end{array}$ & $\begin{array}{c}-0.04^{*} \\
(0.02)\end{array}$ & $\begin{array}{c}-0.02 \\
(0.03)\end{array}$ & $\begin{array}{c}-0.07^{* * *} \\
(0.02)\end{array}$ & $\begin{array}{c}-0.05^{* * *} \\
(0.02)\end{array}$ & $\begin{array}{l}-0.01 \\
(0.02)\end{array}$ & $\begin{array}{c}-0.09^{* * *} \\
(0.02)\end{array}$ & $\begin{array}{c}-0.09^{* * *} \\
(0.01)\end{array}$ & $\begin{array}{c}-0.08^{* * *} \\
(0.02)\end{array}$ & $\begin{array}{c}-0.04^{*} \\
(0.02)\end{array}$ \\
\hline Log initial EXPY & $\begin{array}{l}0.12^{*} \\
(0.07)\end{array}$ & $\begin{array}{c}0.07 \\
(0.07)\end{array}$ & $\begin{array}{c}0.05 \\
(0.07)\end{array}$ & $\begin{array}{l}0.12^{* *} \\
(0.06)\end{array}$ & $\begin{array}{c}0.09 \\
(0.06)\end{array}$ & $\begin{array}{c}0.03 \\
(0.05)\end{array}$ & $\begin{array}{c}0.23^{* * *} \\
(0.06)\end{array}$ & $\begin{array}{c}0.22^{* * *} \\
(0.03)\end{array}$ & $\begin{array}{l}0.14^{*} \\
(0.08)\end{array}$ & $\begin{array}{c}0.01 \\
(0.07)\end{array}$ \\
\hline Log initial Population & - & $\begin{array}{c}0.02^{* * *} \\
(0.01)\end{array}$ & $\begin{array}{c}0.02^{* * *} \\
(0.01)\end{array}$ & - & $\begin{array}{c}0.03^{* * *} \\
(0.01)\end{array}$ & $\begin{array}{c}0.02^{* * * *} \\
(0.05)\end{array}$ & - & $\begin{array}{c}0.03^{* * *} \\
(0.01)\end{array}$ & - & $\begin{array}{c}0.03^{* * *} \\
(0.01)\end{array}$ \\
\hline Initial Rule of law & - & - & $\begin{array}{l}-0.03 \\
(0.02)\end{array}$ & - & - & $\begin{array}{c}-0.05^{* *} \\
(0.02)\end{array}$ & - & $\begin{array}{l}0.11^{* *} \\
(0.04)\end{array}$ & - & - \\
\hline Constant & $\begin{array}{l}-0.22 \\
(0.50)\end{array}$ & $\begin{array}{c}-0.04 \\
(0.51)\end{array}$ & $\begin{array}{l}-0.05 \\
(0.51)\end{array}$ & $\begin{array}{l}-0.10 \\
(0.46)\end{array}$ & $\begin{array}{l}-0.15 \\
(0.43)\end{array}$ & $\begin{array}{c}0.06 \\
(0.40)\end{array}$ & $\begin{array}{c}-1.01^{* *} \\
(0.04)\end{array}$ & $\begin{array}{c}-1.22^{* * *} \\
(0.25)\end{array}$ & $\begin{array}{l}-0.13 \\
(0.57)\end{array}$ & $\begin{array}{c}0.40 \\
(0.53)\end{array}$ \\
\hline $\mathrm{R}^{2}$ & 0.06 & 0.10 & 0.11 & 0.10 & 0.15 & 0.16 & 0.46 & 0.80 & 0.10 & 0.27 \\
\hline P-value & 0.02 & 0.00 & 0.00 & 0.00 & 0.00 & 0.00 & 0.00 & 0.00 & 0.00 & 0.00 \\
\hline No. of observations & 176 & 176 & 176 & 176 & 176 & 176 & 36 & 36 & 140 & 140 \\
\hline
\end{tabular}

Note: Dependent variable: log of growth over 2004-2013. Models 7 and 8 include only countries and territories with highly concentrated exports of primary commodities, where exports of one commodity exceed $50 \%$ of total export value. Models 9 and 10 apply to all other countries and territories. Robust standard errors in parentheses. ${ }^{* *}$ Significant at $1 \%$ level. ${ }^{* *}$ Significant at $5 \%$ * Significant at $10 \%$.

Source: Own calculations based on "UNCTADstat", by the UNCTAD (2014). Retrieved from http://unctadstat.unctad.org/wds/ ReportFolders/reportFolders.aspx; “GDP per capita, PPP (current international \$)”, by The World Bank (2014a). Retrieved from http://data.worldbank.org/indicator/NY.GDP.PCAP.PP.CD

only in countries with high exports of primary commodities, where high EXPY values do not correlate with export sophistication level, but are mainly a result of oil exports.

A shortcoming of the regressions is possible omitted variable bias. Additionally, the analysis is based on a relatively low level of product disaggregation, using three digit level SITC, Rev. 3 commodity classification, as opposed to typically employed UN Comtrade 4-digit data. On the other hand, a clear advantage of our approach over HHR's and other similar studies is that it takes into account data for a wide group of 176 countries and territories of the world (in comparison, HHR only use 42-85 countries).

\section{EXPY and terms of trade}

An important indicator of a country's trade performance is the terms of trade index, a ratio of export prices to import prices. An improvement of a country's terms of trade means that it is able to exchange the same amount of exports for a higher amount of imports. It can be expected that rising export sophistication should be linked to rising terms of trade. Saadi (2012), however, has shown that increase in the sophistication of developing countries' exports is accompanied by a deterioration of their terms of trade. He offers several explanations of this counterintuitive result, including excess production capacity, technological upgrading without simultaneous advances 

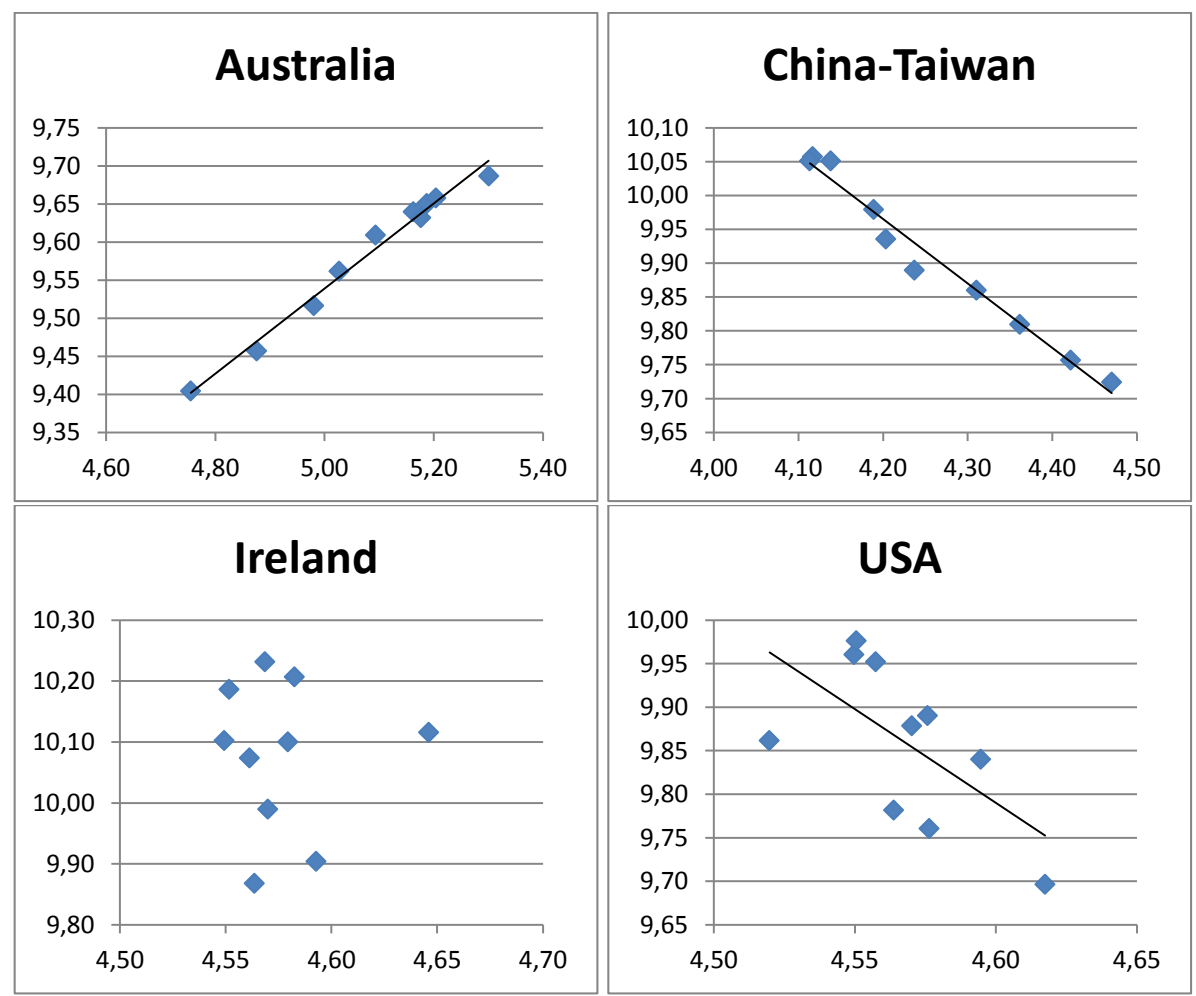

Figure 1. Relationship between EXPY and terms of trade, 2014-2013 (selected countries)

Note: Horizontal axes - log TOT. Vertical axes - log EXPY

Source: Own calculations based on “UNCTADstat", by the UNCTAD (2014). Retrieved from http://unctadstat.unctad.org/wds/ ReportFolders/reportFolders.aspx; “GDP per capita, PPP (current international \$)”, by The World Bank (2014a). Retrieved from http://data.worldbank.org/indicator/NY.GDP.PCAP.PP.CD

on the product quality ladder, and the product cycle. Unfortunately, Saadi's test is restricted to 52 developing countries and does not include any analysis of the situation in the developed world. Using data on 203 countries and territories over the period 2004-2013, our approach offers a much broader picture.

To provide an overview of the situation, we begin by creating plot charts of the intertemporal relationship between EXPY and net barter terms of trade for all countries in our data set. Several of these are displayed in figure 1. As observed, the charts are dramatically different. In Australia, an almost perfect positive relationship exists between the two variables. Conversely, in Taiwan the relationship is almost perfectly negative. A negative link can also be observed in the case of the USA. Ireland's chart shows no sign of any relationship and the pattern appears to be random. The four charts presented in the figure are only a small sample, yet the majority of other countries and territories follow one of these patterns. 
Table 4. Countries with the highest EXPY - terms of trade correlations, 2004-2013

\begin{tabular}{cc}
\hline High positive correlations (>0.80) & High negative correlations $(<-\mathbf{0 . 8 0 )}$ \\
\hline Argentina, Australia, Benin, Bolivia, Brazil, Bulgaria, & Austria, Belgium, Central African Republic, Costa Rica, \\
Colombia, Egypt, Equatorial Guinea, Ethiopia, Fiji, & Czech Republic, El Salvador, Finland, France, Greece, \\
Georgia, India, Indonesia, Kazakhstan, Mali, Malta, & China, China-Hong Kong, China-Taiwan, Italy, Japan, \\
Mauritania, New Zealand, Norway, Papua New Guinea, & Lithuania, Luxembourg, Mauritius, Nauru, Nepal, \\
Romania, Suriname, United Arab Emirates, United & Netherlands, Panama, Philippines, Poland, Republic of \\
Republic of Tanzania, Yemen & Korea, Saint Kitts and Nevis, Samoa, Singapore, Slovakia, \\
& Slovenia, Spain, Sri Lanka, Sweden, TFYR of Macedonia, \\
& Turkey, Turks and Caicos Islands \\
\hline
\end{tabular}

Note: Pearson correlation coefficient between log EXPY and log TOT.

Source: Own calculations based on "UNCTADstat", by the UNCTAD (2014). Retrieved from http://unctadstat.unctad.org/wds/ ReportFolders/reportFolders.aspx; "GDP per capita, PPP (current international \$)", by The World Bank (2014a). Retrieved from http://data.worldbank.org/indicator/NY.GDP.PCAP.PP.CD

Dramatic differences between the countries are also confirmed by correlation analyses. Pearson's correlation coefficients of the intertemporal relationship between EXPY and the net barter terms of trade range from 0.99 in Australia to -0.99 in Taiwan, with an average of 0.03 and median value of 0.14 . While 26 nations have a significant positive coefficient of 0.80 or above, 35 other nations have a significant negative coefficient of -0.80 or lower (Table 4 ). It appears that the majority of the countries with negative correlation are highincome developed nations. On the contrary, countries with a high positive correlation include numerous primary commodities dependent developing countries, which contradicts Saadi's results.

The preliminary analysis suggests that there are important differences in the effect of export sophistication on terms of trade among different groups of countries. It appears that these differences may be connected to the countries' per capita incomes and their development status. We will test this claim using pooled OLS and heteroskedasticity-corrected OLS regression analyses with time specific effects. Following Saadi (2012), in addition to the log of EXPY, we will also use log of imports divided by GDP as a control variable. This is based on the empirical assumption that countries with a higher share of imports on GDP (and hence higher trade openness) are more dependent on foreign suppliers and their demand is inelastic to price changes. As a result, a negative sign of the coefficient is expected.
Regressions using data for all countries and territories show a statistically significant positive link between EXPY and terms of trade (Table 4, Models 1 and 4). Overall, increases in export sophistication lead to an enhancement of the terms of trade. The models have a very low $\mathrm{R}^{2}$, however, which indicates that there is an important share of unexplained variation in the dependent variable. If separate models are estimated for countries and territories with highly concentrated exports of primary commodities and the rest of the world, the results are considerably different. The former group shows a statistically highly significant positive link between EXPY and terms of trade with a relatively large $\mathrm{R}^{2}$. A $10 \%$ increase in EXPY leads to a $4.1 \%-4.3 \%$ enhancement of the terms of trade. EXPY is clearly capturing the effect of rising prices of primary commodities here and is not a good indicator of export sophistication. Conversely, the latter group shows no statistically significant relationship between the variables. Yet if the group is further subdivided according to income (based on the The World Bank 2004 classification), a clear pattern emerges - in lowincome countries, increases in EXPY lead to a deterioration of the terms of trade, whereas in middle-income countries, a terms-of-trade enhancing effect can be observed. In high-income countries, no significant relationship exists.

The negative relationship between the variables in low-income countries partially confirms Saadi's (2012) conclusions, but their validity appears to be limited 
Table 5. EXPY - terms of trade regressions, 2004-2013

\begin{tabular}{|c|c|c|c|c|c|c|c|c|c|c|c|}
\hline & \multicolumn{4}{|c|}{ Pooled OLS } & \multicolumn{7}{|c|}{ Heteroskedasticity-corrected OLS } \\
\hline & \multicolumn{4}{|c|}{ Export concentration } & \multicolumn{2}{|c|}{$\begin{array}{c}\text { Export } \\
\text { concentration }\end{array}$} & \multicolumn{5}{|c|}{ Other by income level } \\
\hline & $\begin{array}{l}\text { (1) } \\
\text { All }\end{array}$ & $\begin{array}{c}(2) \\
\text { Primary }\end{array}$ & $\begin{array}{c}(3) \\
\text { Other }\end{array}$ & $\begin{array}{l}(4) \\
\text { All }\end{array}$ & $\begin{array}{c}\text { (5) } \\
\text { Primary }\end{array}$ & $\begin{array}{c}(6) \\
\text { Other }\end{array}$ & $\begin{array}{l}(7) \\
\text { Low }\end{array}$ & $\begin{array}{c}\text { (8) } \\
\text { L. } \\
\text { middle }\end{array}$ & $\begin{array}{c}\text { (9) } \\
\text { U. } \\
\text { middle }\end{array}$ & $\begin{array}{l}(10) \\
\text { High }\end{array}$ & $\begin{array}{c}\text { (11) } \\
\text { High } 2\end{array}$ \\
\hline Log EXPY & $\begin{array}{l}0.11^{*} \\
(0.06)\end{array}$ & $\begin{array}{c}0.42^{* * *} \\
(0.07)\end{array}$ & $\begin{array}{l}-0.09 \\
(0.07)\end{array}$ & $\begin{array}{c}0.11^{* * *} \\
(0.08)\end{array}$ & $\begin{array}{c}0.44^{* * *} \\
(0.02)\end{array}$ & $\begin{array}{l}-0.02 \\
(0.02)\end{array}$ & $\begin{array}{c}-0.17^{* * *} \\
(0.05)\end{array}$ & $\begin{array}{l}0.07^{* *} \\
(0.03)\end{array}$ & $\begin{array}{c}0.09^{* * *} \\
(0.03)\end{array}$ & $\begin{array}{l}-0.09 \\
(0.06)\end{array}$ & $\begin{array}{c}-0.10^{* *} \\
(0.05)\end{array}$ \\
\hline $\begin{array}{l}\text { Log Imports/ } \\
\text { GDP }\end{array}$ & $\begin{array}{c}-0.18^{* * *} \\
(0.03)\end{array}$ & $\begin{array}{c}-0.20^{* * *} \\
(0.05)\end{array}$ & $\begin{array}{c}-0.09^{* *} \\
(0.04)\end{array}$ & $\begin{array}{c}-0.08^{* * *} \\
(0.01)\end{array}$ & $\begin{array}{c}-0.13^{* * *} \\
(0.02)\end{array}$ & $\begin{array}{c}-0.05^{* * *} \\
(0.01)\end{array}$ & $\begin{array}{l}-0.06^{*} \\
(0.03)\end{array}$ & $\begin{array}{c}-0.10^{* * *} \\
(0.02)\end{array}$ & $\begin{array}{c}-0.14^{* * *} \\
(0.02)\end{array}$ & $\begin{array}{l}-0.02 \\
(0.01)\end{array}$ & $\begin{array}{c}-0.03^{* *} \\
(0.01)\end{array}$ \\
\hline Constant & $\begin{array}{c}3.45^{* * *} \\
(0.59)\end{array}$ & $\begin{array}{c}0.78 \\
(0.64)\end{array}$ & $\begin{array}{c}5.42^{* * *} \\
(0.72)\end{array}$ & $\begin{array}{c}3.49^{* * *} \\
(0.15)\end{array}$ & $\begin{array}{c}0.71^{* * *} \\
(0.20)\end{array}$ & $\begin{array}{c}4.76^{* * *} \\
(0.17)\end{array}$ & $\begin{array}{c}6.22^{* * *} \\
(0.47)\end{array}$ & $\begin{array}{c}3.90^{* * *} \\
(0.25)\end{array}$ & $\begin{array}{c}3.57^{* * *} \\
(0.25)\end{array}$ & $\begin{array}{c}5.45^{* * *} \\
(0.59)\end{array}$ & $\begin{array}{c}5.51^{* * *} \\
(0.50)\end{array}$ \\
\hline $\mathbf{R}^{2}$ & 0.12 & 0.63 & 0.04 & 0.06 & 0.71 & 0.02 & 0.04 & 0.13 & 0.27 & 0.01 & 0.04 \\
\hline P-value & 0.00 & 0.00 & 0.00 & 0.00 & 0.00 & 0.00 & 0.02 & 0.00 & 0.00 & 0.92 & 0.19 \\
\hline $\begin{array}{l}\text { No. of } \\
\text { countries }\end{array}$ & 203 & 41 & 162 & 203 & 41 & 162 & 52 & 40 & 32 & 38 & 37 \\
\hline $\begin{array}{l}\text { No. of } \\
\text { observations }\end{array}$ & 1991 & 404 & 1587 & 1991 & 404 & 1587 & 500 & 396 & 320 & 371 & 361 \\
\hline
\end{tabular}

Note: Dependent variable: log TOT. Models 2 and 5 include only countries and territories with highly concentrated exports of primary commodities, where exports of one commodity exceed $50 \%$ of total export value. Models 3, 6 and 7-10 apply to all other countries and territories. Model 11 excludes United Arab Emirates from the high-income group (see text). Income levels based on 2004 World Bank classification: Low income $<=825 \$$, lower middle income $826 \$-3,255 \$$, upper middle income $3,256 \$-10,065 \$$, high income $>=10,066 \$$. Robust standard errors in parentheses. Time specific effects used in each regression. *** Significant at $1 \%$ level. ** Significant at $5 \%$. ${ }^{*}$ Significant at $10 \%$.

Source: Own calculations based on "UNCTADstat", by the UNCTAD (2014). Retrieved from http://unctadstat.unctad.org/wds/ ReportFolders/reportFolders.aspx; "GDP per capita, PPP (current international \$)", by The World Bank (2014a). Retrieved from http://data.worldbank.org/indicator/NY.GDP.PCAP.PP.CD; "GNI per capita, Atlas method (current US\$)", by the World Bank (2014b). Retrieved from http://data.worldbank.org/indicator/NY.GNP.PCAP.CD

only to the poorest developing countries with no substantial exports of primary commodities and not to developing countries in general. These mixed results indicate that the same economic phenomenon can have very dissimilar effects in different country groups. Rising export sophistication brings positive consequences for middle-income countries but clearly worsens the situation of the poorest nations. This is probably a result of two factors: (1) The prices of primary commodities have increased more than two-fold in the last decade, negatively influencing the imports of the poor- est nations. (2) Rising export sophistication in absolute terms does not necessary mean that exports have increased in relative terms as well, nor that the country has been successfully climbing the product quality ladder. The poorest nations are not able to successfully cope with this issue.

While not statistically significant, the negative linkage between EXPY and terms of trade in high-income countries shown in column 10 of the table might be explained by the immiserizing growth process. A thorough review of high-income countries' data uncovers 
that the United Arab Emirates (UAE), a strong oil exporter, is present in the group. As shown in Table 3, there are clear differences between natural-resources exporting countries and other exporters. Therefore, we exclude the UAE from the high-income countries group; once this is done, the negative linkage becomes statistically significant at the $5 \%$ level and immiserizing growth is confirmed.

\section{Conclusion}

Previous research by Hausmann, Hwang and Rodrik using data for 1962-2003 indicated that export specialization patterns have important implications for economic growth. According to their study, higher export sophistication leads to stronger subsequent growth. Our test has shown that, on the aggregate level, the link is still valid even in the current period of global economic crisis and ensuing changes. The relationship is stronger and much more statistically significant in countries that focus heavily on the export of primary commodities than in other countries. Similar results have been achieved when regressing the net barter terms of trade on export sophistication. While primary-commodities exporting countries and mediumincome nations display a positive relationship between the variables, it is negative for non-resource-based low-income countries, effectively meaning that a rise in export sophistication deteriorates their terms of trade. This is a paradoxical result that can be explained by the rapid increase in prices of primary commodities in the period studied and by the fact that an absolute increase in export sophistication does not mean that relative export sophistication has increased as well. As a result, it appears that EXPY is not a good predictor of future economic performance when the prices of primary commodities are unstable.

To conclude, what is the solution to the question asked in the title of this paper? Our answer is very different from that offered by previous literature - on the one hand, it matters what you export, but on the other, it does not! This claim may sound strange, but it has a simple explanation. If the prices of primary commodities are stable, focusing on the export of sophisticated goods generates higher economic growth in the future, as was shown by HHR. If the prices of primary commodities are on the rise, however, the effects can be exactly the opposite. This means that depending on the actual economic environment, countries can see very different results by focusing on the export of different goods. Hence, it matters what you export. On the other hand, we have shown that countries can successfully grow and enhance their terms of trade not only by exporting highly sophisticated goods but also by exporting primary commodities. Hence, it does not really matter what you export; it mainly matters when you export it. No absolute truth exists and the crucial task of policy makers is to make the right export decisions at the right time.

\section{References}

Acemoglu, D., Johnson, S., \& Robinson, J. A. (2001). The colonial origins of comparative development: an empirical investigation. American Economic Review, 91 (5), 1369-1401.

Barro, R. J. (1997). Determinants of Economic Growth: A Cross-Country Empirical Study. Cambridge, MA: MIT Press.

Bernatonyte, D. (2011). Export productivity and specialization patterns of Lithuania. Economics \& Management, 16, 109-115.

Crespo Cuaresma, J., Doppelhofer, G., \& Feldkircher, M. (2014). The Determinants of Economic Growth in European Regions. Regional Studies, 48 (1), 44-67.

Diamond, J. (1997). Guns, Germs, and Steel: The Fates of Human Societies. New York, NY: W. W. Norton \& Company.

Hausmann, R., Hwang, J., \& Rodrik, D. (2007). What you export matters. Journal of Economic Growth, 12 (1), 1-25.

Jarreau, J., \& Poncet, S. (2011). Export sophistication and economic growth: Evidence from China. Journal of Development Economics, 97 (2), 281-292.

Johnson, R. C. (2014). Five Facts about Value-Added Exports and Implications for Macroeconomics and Trade Research. Journal of Economic Perspectives, 28 (2), 119-142.

Kremer, M. (1993). Population Growth and Technological Change: One Million B.C. to 1990. The Quarterly Journal of Economics, 108 (3), 681-716.

Lall, S., Weiss, J., \& Zhang, J. K. (2006). The "sophistication" of exports: A new trade measure. World Development, 34 (2), 222-237. 
Lipkova, L. (2012). Medzinarodne hospodarske vztahy [International Economic Relations]. Bratislava: Sprint dva.

Michaely, M. (1984). Trade, income levels, and dependence. Amsterdam: North-Holland.

Minondo, A. (2010a). Exports' quality-adjusted productivity and economic growth. The Journal of International Trade \& Economic Development, 19 (2), 257-287.

Minondo, A. (2010b). Exports' Productivity and Growth across Spanish Regions. Regional Studies, 44 (5), 569-577.

Nyarko, Y. (2013). Sustaining High Economic Growth in Sub-Saharan Africa: Knowledge and the Structure of the Economy. Journal of African Economies, 22, 77-101

Próchniak, M. (2011). Determinants of Economic Growth in Central and Eastern Europe: The Global Crisis Perspective. Post-Communist Economies, 23 (4), 449-468.

Saadi, M. (2012). Export sophistication and the terms of trade of the developing and emerging countries. International Review of Applied Economics, 26 (5), 623-642.

Santos-Paulino, A. U. (2010). Export productivity and specialization: a disaggregated analysis. The World Economy, 33 (9), 1095-1116.

Santos-Paulino, A. U. (2011). Trade specialization, export productivity and growth in Brazil, China, India, South Africa, and a cross section of countries. Economic Change and Restructuring, 44 (1), 75-97.

The World Bank. (2014a). GDP per capita, PPP (current international \$). Retrieved from http://data. worldbank.org/indicator/NY.GDP.PCAP.PP.CD

The World Bank. (2014b). GNI per capita, Atlas method (current US\$). Retrieved from http://data. worldbank.org/indicator/NY.GNP.PCAP.CD

The World Bank. (2014c). Worldwide Governance Indicators. Retrieved from http://info.worldbank. org/governance/wgi/index.aspx\#home

UNCTAD (2014). UNCTADstat. Retrieved from http://unctadstat.unctad.org/wds/ReportFolders/ reportFolders.aspx

Wang, Z., Wei, S., \& Wong, A. (2010). Does a leapfrogging growth strategy raise the growth rate? Some international evidence (Working Paper No. 16390). The National Bureau of Economic Research.
Weber, M. (1950). Die protestantische Ethik und der Geist des Kapitalismus [The Protestant Ethic and the Spirit of Capitalism] (T. Parsons, Trans.). New York, NY: Charles Scribner's Sons.

Weiss, J. (2010). Changing Trade Structure and its Implications for Growth. The World Economy, 33 (10), 1269-1279.

\section{Endnotes}

1 For detailed information about this method and calculation examples, please see the The World Bank's website at https://datahelpdesk.worldbank. org/knowledgebase/articles/378832-what-is-theworld-bank-atlas-method.

\section{Acknowledgements}

This research has been conducted with the financial support from the Ministry of Education, Science, Research and Sport of the Slovak Republic, KEGA grant agency, grant number 017EU-4/2015. 


\section{Appendix}

Appendix. Countries and territories included in the study based on their 2004 income level

\section{Low income <=825\$:}

Afghanistan, Anguilla, Bangladesh, Bermuda, British Virgin Islands, Burundi, Cambodia, Cameroon, Cayman Islands, Central African Republic, Cook Islands, Côte d'Ivoire, Dem. People's Rep. of Korea, Dem. Rep. of the Congo, Eritrea, Ethiopia, Gambia, Ghana, Haiti, India, Kenya, Kyrgyzstan, Lao People's Dem. Rep., Lesotho, Liberia, Madagascar, Mauritania, Mongolia, Montserrat, Myanmar, Nauru, Nepal, New Caledonia, Niger, Pakistan, Papua New Guinea, Republic of Moldova, Sao Tome and Principe, Senegal, Serbia and Montenegro, Sierra Leone, State of Palestine, Tajikistan, Togo, Turks and Caicos Islands, Uganda, United Republic of Tanzania, Uzbekistan, Viet Nam, Zambia, Zimbabwe

\section{Lower middle income $826 \$-3,255 \$$ :}

Albania, Armenia, Belarus, Bhutan, Bolivia, Bosnia and Herzegovina, Bulgaria, Cabo Verde, China, Colombia, Djibouti, Dominican Republic, Egypt, El Salvador, Fiji, Georgia, Guatemala, Guyana, Honduras, Indonesia, Jordan, Kiribati, Montenegro, Morocco, Namibia, Nicaragua, Paraguay, Peru, Philippines, Romania, Samoa, Serbia, Sri Lanka, Suriname, Swaziland, Syrian Arab Republic, Thailand, TFYR of Macedonia, Tonga, Tunisia, Ukraine

\section{Upper middle income 3,256\$-10,065\$:}

Argentina, Belize, Brazil, Chile, Costa Rica, Croatia, Cuba, Czech Republic, Dominica, Estonia, Grenada, Hungary, Latvia, Lebanon, Lithuania, Malaysia, Maldives, Marshall Islands, Mauritius, Mexico, Panama, Poland, Russian Federation, Saint Kitts and Nevis, Saint Lucia, Saint Vincent and the Grenadines, Seychelles, Slovakia, South Africa, Trinidad and Tobago, Turkey, Tuvalu, Uruguay

\section{High income $>=10,066 \$$ :}

Andorra, Antigua and Barbuda, Australia, Austria, Bahamas, Bahrain, Barbados, Belgium, Canada, Cyprus, Denmark, Finland, France, Germany, Greece, Greenland, Hong Kong, Iceland, Ireland, Israel, Italy, Japan, Luxembourg, Macao, Malta, Netherlands, New Zealand, Norway, Portugal, Republic of Korea, Singapore, Slovenia, Spain, Sweden, Switzerland, United Arab Emirates, United Kingdom, United States

Source: Own elaboration based on "GNI per capita, Atlas method (current US\$)", by the World Bank (2014b). Retrieved from http://data.worldbank.org/indicator/NY.GNP.PCAP.CD 